\title{
Detection of TSH-Binding Inhibitor Immunoglobulins by Using the Triton-Solubilized Receptor from Human Thyroid Membranes
}

\author{
YASUHIRO IIDA, JUNJI KONISHI, KANJI KASAGI, \\ KANJI KUMA* AND KANII TORIZUKA \\ Department of Nuclear Medicine, Kyoto University School of \\ Medicine, Kyoto 606 and *Kuma Hospital, Kobe 650, Japan
}

\begin{abstract}
A radioreceptor assay of TSH using Triton-solubilized human thyroid receptors was applied to the detection of TSH-binding inhibitor immunoglobulins (TBII). In 26 untreated patients with Graves' disease, $20(76.9 \%)$ were found positive in this assay, while $18(69.2 \%)$ cases were found positive by the conventional assay using human thyroid particulate receptors. In 25 patients with goitrous Hashimoto's thyroiditis, $2(8.0 \%)$ were found positive by the assay using soluble receptor, while $3(12.0 \%)$ were found positive by the conventional one. A significant correlation was found between TBII activities in the patients with untreated Graves' disease detected by these two assay systems $(r=0.69$; $\mathrm{n}=26 ; \mathrm{p}<0.001)$. These data support the concept that TBII are antibodies against the TSH receptor or its closely related structures.
\end{abstract}

By using the radioreceptor assay of TSH, immunoglobulins which inhibit TSH binding to human thyroid membranes have been detected in the sera of patients with Graves' disease (Manley et al., 1974; Smith and Hall, 1974; Mehdi and Nussey, 1975; Bryson et al., 1976; Petersen et al., 1977; Endo et al., 1978; O’Donnel et al., 1978).

These immunoglobulins, originally called thyroid stimulating immunoglobulins by Smith and Hall (1974), are more appropriately termed TSH-binding inhibitor immunoglobulins (TBII) (Endo et al., 1978), and are now considered to be antibodies to portion of the thyroid plasma membranes including the TSH receptor (Volpé, 1978; Editorial, 1979). In these studies, the particulate fraction of the human thyroid homogenate has been used as receptor (Smith and

Received January 21, 1982
Hall, 1974; Mehdi and Nussey, 1975; Bryson et al., 1976; Endo et al., 1978; O’Donnel et al., 1978).

It was reported that the TSH receptor could be solubilized with non-ionic detergents and the solubilized receptor maintain its binding activity (Tate et al., 1975a, b; Petersen et al., 1977; Czarnocka et al., 1979; Iida et al., 1981). However, no detailed study on the detection of TBII using soluble receptor has yet been reported.

In the present study, a radioreceptor assay for TBII activity by using Triton-solubilized human thyroid receptors was developed and the assay results were compared with those obtained by using particulate receptors.

\section{Materials and methods}

Patients

Sera were obtained from 26 patients with untreated Graves' disease, 25 patients with goitrous 
Hashimoto's thyroiditis and 16 laboratory personnel who served as normal control subjects. The clinical diagnoses of patients were based on clinical findings, measurement of serum $\mathrm{T}_{3}, \mathrm{~T}_{4}$, anti-thyroglobulin antibody, anti-microsome antibody, scintigraphic examination and histology of needle biopsy specimen of the thyroid.

\section{Preparation of immunoglobulin $G$ ( $I g G)$}

IgG were prepared from the sera by column chromatography through DEAE-Sephadex (Baumstark et al., 1964). The protein concentration was measured by the method of Lowry et al. (1951) using bovine serum albumin as the standard.

\section{Radioiodination of TSH}

Highly purified bovine TSH $(40 \mathrm{IU} / \mathrm{mg})$ was a generous gift from Dr. John G. Pierce (Los Angeles, CA). It was iodinated by the lactoperoxidase method (Miyachi et al., 1972) and purified further by receptor absorption (Manley et al., 1974).

\section{Radioreceptor assay using particulate receptors}

Radioreceptor assay using particulate receptor was performed according to Endo et al. (1978). The thyroid gland was obtained from a single patient with Graves' disease at the time of operation. $100 \mu 1 \quad 10,000 \times \mathrm{g}$ fraction of human thyroid homogenate (about $500 \mu \mathrm{g}$ protein, $100 \mathrm{mg}$ wet tissue equivalent), $50 \mu 1$ [ $\left.{ }^{125} \mathrm{I}\right] \mathrm{TSH}$ and $150 \mu 1100 \mathrm{mM}$ Tris, $50 \mathrm{mM} \mathrm{NaCl}$ with $1 \mathrm{mg} \mathrm{IgG}$ were incubated for $60 \mathrm{~min}$. at $37^{\circ} \mathrm{C}$. Subsequently $500 \mu \mathrm{l} \quad 0.32 \%$ human $\gamma$-globulin and $800 \mu \mathrm{l} \quad 20 \%$ polyethylene glycol (PEG), $2 \mathrm{M} \mathrm{NaCl}$ were added. After vortexing and leaving for $10 \mathrm{~min}$. at $4^{\circ} \mathrm{C}$, the mixture was centrifuged at $3,000 \times \mathrm{g}$ for $20 \mathrm{~min}$. and the radioactivity in the pellet was measured in a $\gamma$ counter.

The result was expressed as a percentage of the mean value of the TSH specifically bound in the presence of 16 normal IgGs. Specific binding was obtained by subtracting [ ${ }^{[25}$ I]TSH bound to the receptor in the presence of $100 \mathrm{mU} / \mathrm{ml}$ unlabeled bTSH (Thytropar ${ }^{\circledR}$, Armor Pharm. Co.). The TBII activities of patients were measured in a single assay.

\section{Radioreceptor assay using Triton-solubilized receptor}

Solubilization of TSH receptors was performed from human thyroid obtained from patients with Graves' disease at the time of operation by using $0.5 \%$ Triton X-100 by the method of Petersen et al. (1977) with minor modification (Iida et al., 1981).

Radioreceptor assay using Triton-solubilized receptor was performed as follows: $100 \mu \mathrm{l}$ Tritonsolubilized receptor ( $200 \mu \mathrm{g}$ protein, $200 \mathrm{mg}$ wet tissue equivalent), $50 \mu \mathrm{l}{ }^{\left[{ }^{125} \mathrm{I}\right] \mathrm{TSH}}$ and $50 \mu \mathrm{l} 10 \mathrm{mM}$ Tris, $50 \mathrm{mM} \mathrm{NaCl}$ with $1 \mathrm{mg}$ IgG were incubated for 60 min. at $25^{\circ} \mathrm{C}$. Subsequently, $500 \mu 10.32 \%$ human $\gamma-$ globulin and $700 \mu 130 \%$ PEG, $1 \mathrm{M} \mathrm{NaCl}$ were added.
After centrifugation, the radioactivity in the pellet was measured as in the assay using particulate receptor.

\section{Results}

Detection of TBII by using particulate receptors

When the particulate receptors were used, about $15 \%$ of $\left[{ }^{125} \mathrm{I}\right] \mathrm{TSH}$ were specifically bound. TBII activities ranged from 83.6$116.7 \%(100 \pm 9.6 \%$; mean $\pm S D)$ in 16 normal controls. Taking the lower limit of normal as mean-2SD for normal subjects, positive TBII were found in $18(69.2 \%)$ out of 26 patients with untreated Graves' disease and $3(12.0 \%)$ out of 25 patients with goitrous Hashimoto's thyroiditis (Fig. 1).

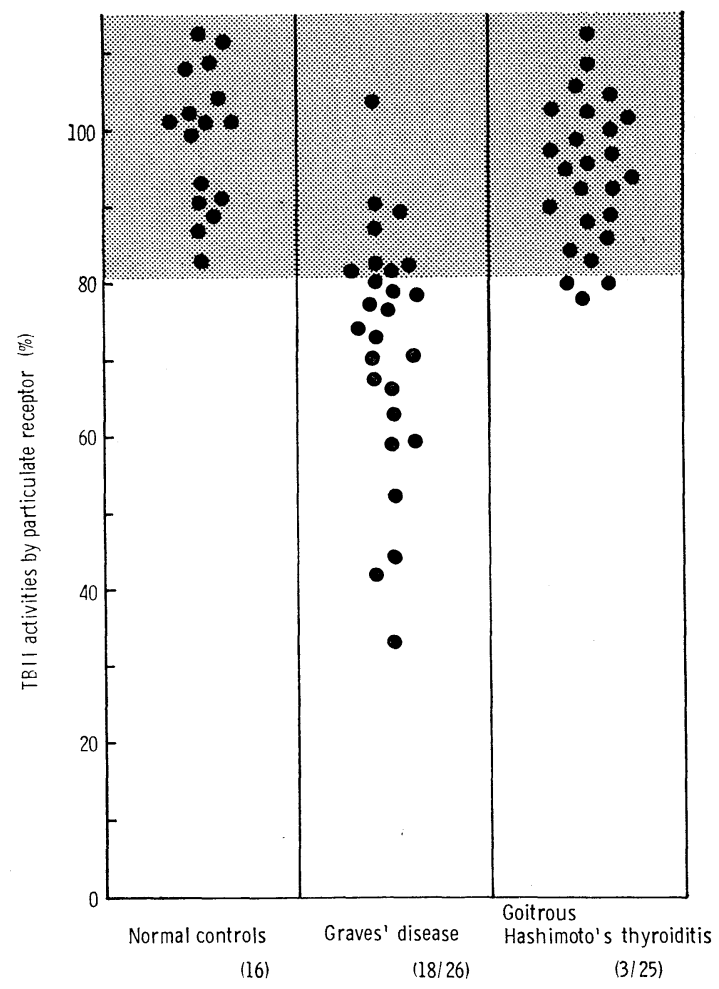

Fig. 1. Detection of TSH-binding inhibitor immunoglobulins (TBII) in normal controls and patients with untreated Graves' disease and goitrous Hashimoto's thyroiditis using conventional particulate TSH-receptors. 


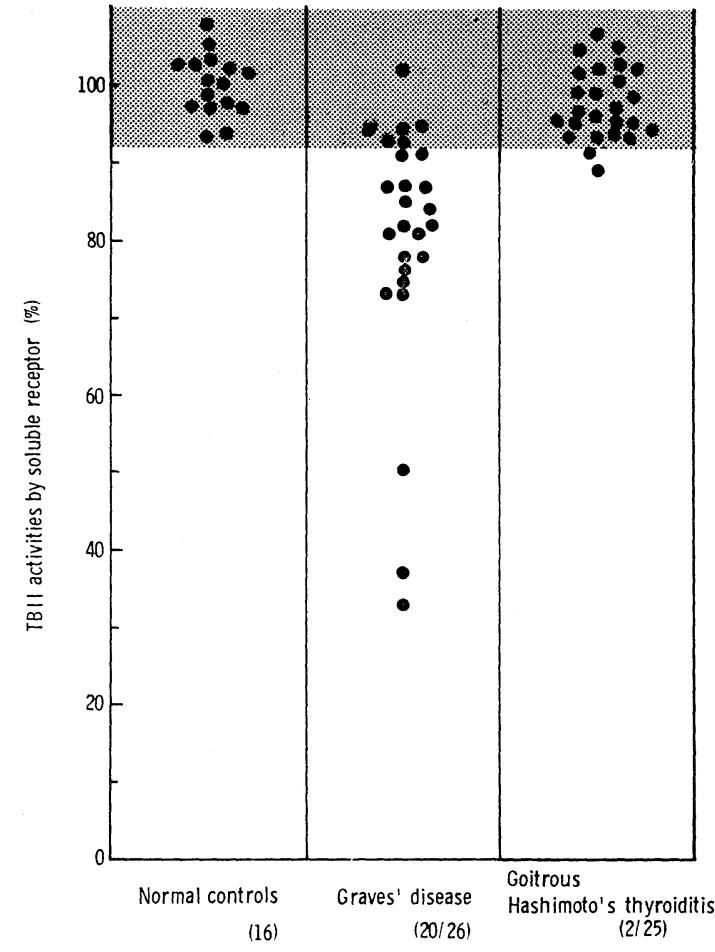

Fig. 2. Detection of TBII in normal controls and patients with untreated Graves' disease and goitrous Hashimoto's thyroiditis using Triton-solubilized TSH-receptors.

Detection of TBII by using Triton-solubilized receptors

By using soluble receptors, binding of $\left[{ }^{125} \mathrm{I}\right] \mathrm{TSH}$ was about $25 \%$. TBII activities in 16 normal controls ranged from $93.2-108.3 \%$ $(100 \pm 3.9 \%$; mean $\pm S D)$ in this assay. Thus TBII activity less than $92.2 \%$ (mean-2SD) was considered to be positive, $20(76.9 \%)$ out of 26 patients with untreated Graves' disease and $2(8.0 \%)$ out of 25 goitrous Hashimoto's thyroiditis were positive for TBII (Fig. 2).

Relation between TBII activities measured by using particulate receptors and those by using soluble receptors

In Fig. 3, TBII activities in the patients with untreated Graves' disease measured by using soluble receptors were plotted against

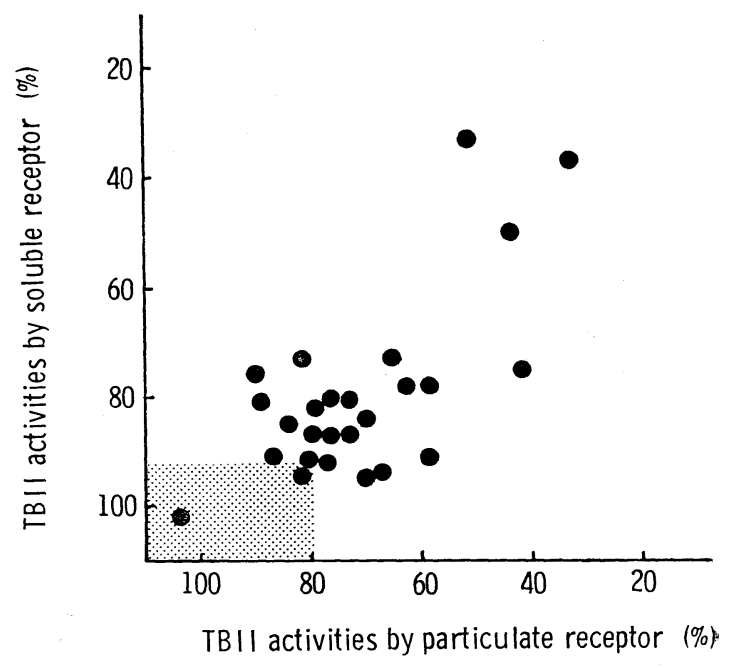

Fig. 3. Relation between TBII detected by the assay using particulate receptors and those by the assay using solubilized receptors in untreated Graves? disease.

those measured by using particulate receptors.

A significant correlation was obtained $(r=$ $0.69, \mathrm{n}=26, \mathrm{p}<0.001$ ) between these two values. However, the results in a few IgGs were discordant in these two assays. Five IgGs which were positive for TBII using solubilized receptors were negative using particulate receptors, while 3 IgGs negative using soluble receptors were positive using particulate receptors. Only $3 \mathrm{IgGs}(11.5 \%)$ were found negative by both assays.

\section{Discussion}

A radioreceptor assay of $\mathrm{TSH}$ using Triton-solubilized human thyroid receptors was applied for the detection of TBII activity in patients with untreated Graves' disease and goitrous Hashimoto's thyroiditis.

In previous studies using particulate receptors, the incidences of TBII in patients with untreated Graves' disease and in those with Hashimoto's thyroiditis have been reported to be from 57 to 93 percent and from 0 to 23 percent, respectively (Mukhtar et al., 
1975; Davies et al., 1977; Schleusener et al., 1977; Endo et al., 1978; Strakosch et al., 1978; O'Donnel et al., 1978; Ozawa et al., 1979; Sugenoya et al., 1979). The marked difference among the reported incidence figures could be due to the differences in procedures and amount or purity of IgGs used in the assay. One of the main factors limiting the detectability of TBII in the receptor assay appears to be the range of inhibition elicited by normal samples.

We showed that Triton-solubilized human thyroid $\mathrm{TSH}$ receptor retained all the basic properties of the membrane receptor and would provide starting material for receptor purification (Iida et al., 1981). Therefore, in this study, we measured TBII activities by using solubilized receptors and compared the results with those obtained by the conventional assay using particulate receptors. In 26 patients with untreated Graves' disease, 77\% showed detectable TBII activity by using soluble receptor in comparison to $69 \%$ by using the latter assay. As for goitrous Hashimoto's thyroiditis, 2 out of 25 patients were positive for TBII by using soluble receptor while 3 were positive by the conventional assay.

TBII activities in untreated Graves' disease measured by these two assay systems showed a significant correlation. The results support the concept that the TBII are interacting against the TSH receptor itself or its closely related structures. In spite of the generally increased detectability of TBII by using soluble receptors, there were few IgGs which were negative in the assay while showing definitely positive result using particulate receptors. These findings may reflect the heterogeneity in antibodies which interfere with the receptor binding of TSH. Thus, the possibility could not be excluded that TBII detected by using the particulate receptor might contain antibodies against membrane antigens not directly related to TSH receptors.

The present study revealed that TBII activity could be measured by the radioreceptor assay using soluble receptors with smaller variability in $\left[{ }^{125} \mathrm{I}\right] \mathrm{TSH}$ binding in the presence of normal IgGs. We believe that further purification of the receptor would make the assay more reliable and specific for TSH receptor-related antibodies in autoimmune thyroid diseases.

\section{Acknowledgements}

We are grateful to Miss Seiko Hattori and Miss Shuko Matsushita for their technical assistance.

This work was supported in part by a Research Grant for Intractable Diseases from the Ministry of Health and Welfare of Japan.

\section{References}

Baumstark, J. S., R. J. Laffin and W. A. Bardawill (1964). A preparative method for the separation of $7 \mathrm{~S}$ gamma globulin for human serum. Arch. Biochem. Biophys. 108, 514.

Bryson, J. M., A. Joasso and J. R. Turtle (1976). The thyrotropin receptor in human thyroid plasma membranes: effect of serum immunoglobulins. Acta Endocrinol (Kbh) 83, 528 .

Czarnocka, B., J. Nauman, G. Adler and W. Kietczynski (1979). Solubilization and partial characterization of thyroid membrane TSH binding protein. Acta Endocrinol. (Kbh) 92, 512.

Davies, T. F., P. P. B. Yeo, D. C. Evered, F. Clark, B. R. Smith and R. Hall (1977). Value of thyroidstimulating antibody determination in predicting short-term thyrotoxic relapse in Graves' disease. Lancet 1, 1181.

Editorial (1979). Four controversies about the cause of hyperthyroidism. Lancet $2,78$.

Endo, K., K. Kasagi, J. Konishi, K. Ikekubo, T. Okuno, Y. Takeda, T. Mori and K. Torizuka (1978). Detection and properties of TSH-binding inhibitor immunoglobulins in patients with Graves' disease and Hashimoto's thyroiditis. J. Clin. Endocrinol. Metab. 46, 734.

Iida, Y., J. Konishi, K. Kasagi, K. Ikekubo, K. Kuma and K. Torizuka (1981). Characterization of Triton-solubilized TSH receptors from human thyroid plasma membranes. Acta Endocrinol. (Kbh) 98, 50.

Lowry, O. H., N. J. Rosebrough, A. L. Farr and R. J. Randall (1951). Protein measurement with the folin phenol reagent. J. Biol. Chem. 193, 265.

Manley, S. W., J. R. Burke and R. W. Howker (1974). The thyrotrophin receptor in guinea pig thyroid homogenates interaction with the long-acting thyroid stimulator. J. Endocrinol. 61, 437.

Mehdi, S. Q. and S. S. Nussey (1975). A radioligand receptor assay for the long-acting thyroid 
stimulator of the binding of radioiodinated thyroidstimulating hormone to human thyroid membranes. Biochem. J. 145, 105.

Miyachi, Y., J. L. Vaitukaitis, E. Nieschlag and M. B. Lipsett (1972). Enzymatic radioiodination of gonadotropins. J. Clin. Endocrinol. Metab. 34, 23.

Mukhtar, E. D., B. R. Smith, G. A. Pyle, R. Hall and P. Vice (1975). Relation of thyroid-stimulating immunoglobulins to thyroid function and effects of surgery, radioiodine and antithyroid drugs. Lancet 1, 713.

O’Donnel, J., K. Trokoudes, J. Silverberg, V. Row and R. Volpé (1978). Thyrotropin displacement activity of serum immunoglobulins from patients with Graves' disease. J. Clin. Endocrinol. Metab. 46, 770.

Ozawa, Y., R. M. Maciel, I. J. Chopra, D. H. Solomon and G. N. Beal (1979). Relationships among immunoglobulin markers in Graves' disease. J. Clin. Endocrinol. Metab. 48, 381.

Petersen, V. B., P. J. D. Dawes, B. R. Smith and R. Hall (1977). The interaction of thyroid-stimulating antibodies with solubilized human thyrotrophin receptors. FEBS Letters $\mathbf{1}, 63$.

Schleusener, H., R. Finke, P. Koyulla, K. W. Wenzel, H. Meinhold and H. D. Roedler (1978). Determina- tion of thyroid stimulating immunoglobulins (TSI) during the cource of Graves' disease. A reliable indicator for remission and persistence of this disease? J. Endocrinol. Invest. 2, 155.

Smith, B. R. and R. Hall (1974). Thyroid-stimulating immunoglobulins in Graves' disease. Lancet 2, 427.

Strakosch, C. R., D. Joyner and J. R. Wall (1978). Thyroid stimulating antibodies in patients with subacute thyroiditis. J. Clin. Endocrinol. Metab. 46, 345.

Sugenoya, A., A. Kidd, V. V. Row and R. Volpé (1979). Correlation between thyrotropin-displacing activity and human thyroid-stimulating activity by immunoglobulins from patients with Graves' disease and other thyroid disorders. J. Clin. Endocrinol. Metab. 48, 398.

Tate, R. L., J. M. Holmes, L. D. Kohn and R. J. Winand (1975a). Characteristics of a solubilized thyrotrophin receptor from bovine thyroid plasma membranes. J. Biol. Chem. 250, 6527.

Tate, R. L., H. I. Schwarz, J. M. Holmes, L. D. Kohn and R. J. Winand (1975b). Thyrotrophin receptors in thyroid plasma membranes. J. Biol. Chem. 250, 6509.

Volpé, R. (1978). The pathogenesis of Graves' disease: an overview. Clin. Endocrinol. Metab. 7, 3. 